\title{
STRATEGI PENYEIMBANGAN ANTARA AKTIVITAS PEKERJAAN DAN KELUARGA PADA WANITA BEKERJA DI BOGOR
}

\author{
Balancing Work and Families Strategis Among Career Women in Bogor \\ Herien Puspitawati ${ }^{1}$ dan Edianna Putri Mayang Sari ${ }^{2}$
}

\begin{abstract}
The main purpose of this research was to know the working women's strategies in balancing between work and domestic activities. Specifically, the objectives were to determine: (1) the contribution of working women in the result of the wealthy of the family, (2) working women's strategy in balancing between work and domestic activities, (3) social support in helping working women in balancing between work and domestic activities, and correlation between variables. The respondents were working women who work in full-time and have a family, consist of husband and a child or children. This was a cross sectional study which was performed among 50 working women in Bogor in March 2005. The results showed that most of respondents balanced between work and family activities. Another strategy that was used by almost all respondents was paying maid to help them in finishing domestic activities. The community and extended families surrounded respondents supported them very well through providing social supports. Working women's strategy had significant correlated with the numbers of children in school-aged, the length of domestic time, and the length of personal time. The overall wellbeing of the family was measured by respondents' satisfaction towards their resource. It was found that the family well-being had significant correlation with the total of husband's income, contribution of respondents' income, extended family social support, and the working women's strategies.
\end{abstract}

Key Words: balancing work and families strategies, family well being

\section{PENDAHULUAN}

Terjadinya ketimpangan antara peran laki-laki dan perempuan di sektor formal. Hal ini terjadi dikarenakan adanya keterbatasan akses perempuan terhadap kesempatan bekerja di sektor formal. Kendala ini kemudian diperparah dengan makin meningkatnya kemiskinan. Strategi yang digunakan untuk mengatasinya adalah dengan melakukan penyeimbangan antara aktivitas pekerjaan dan rumah tangga yang ditandai dengan dimulainya perempuan bekerja di sektor luar agar memenuhi tuntutan secara nasional. Penelitian ini bertujuan untuk mengetahui strategi penyeimbangan antara aktivitas pekerjaan dan keluarga pada perempuan. Secara lebih spesifik, penelitian ini bertujuan untuk: 1) mengetahui kontribusi dan peran perempuan dalam mencapai kesejahteraan keluarga, 2) mengetahui peran keluarga besar dalam membantu perempuan bekerja dan, 3) strategi penerapan antara waktu dan pekerjaan perempuan dalam menyeimbangkan aktivitas pekerjaan dan keluarga.

\section{METODE}

Disain, Tempat, dan Waktu

Penelitian ini menggunakan menggunakan disain cross-sectional. Penelitian dilaksanakan di IPB, SMUN 1 Bogor, PEMDA Kabupaten Bogor, Rumah Sakit Marzoeki Mahdi, dan Hotel Salak. Penelitian dilaksanakan selama enam bulan yaitu bulan Desember 2004 sampai dengan Juli 2005.

\section{Cara Pengambilan Contoh dan Jenis} Data

Contoh penelitian ini adalah perempuan bekerja dengan kriteria: (1) Tingkatan manajerial kelas menengah ke atas, (2) Berkeluarga serta 
mempunyai suami dan anak, dan (3) Bersedia berpartisipasi dalam penelitian ini. Jumlah contoh adalah 50 orang perempuan. Jenis contoh dalam penelitian ini dibagi dalam dua kategori, yaitu pegawai negeri dan pegawai swasta. Pemilihan contoh dilakukan dengan metode purposive sampling. Data yang dikumpulkan adalah data primer dan sekunder. Data primer meliputi karakteristik keluarga, karakteristik perempuan bekerja, indeks dukungan social, keluarga besar, strategi penyeimbangan, dan kesejahteraan keluarga. Data sekunder berupa jumlah pegawai pada instansi atau perusahaan terkait.

\section{Pengolahan dan Analisis Data}

Data karakteristik keluarga, karakteristik individu, dan kontribusi pendapatan istri dianalisis secara deskriptif. Data kehidupan sosial, kesehatan mental/emosi, manajemen keuangan, waktu dan pekerjaan, serta stress, strategi penyeimbangan, kesejahteraan keluarga, dan indeks dukungan sosial dikategorikan berdasarkan modus jawaban tiap responden untuk keseluruhan pertanyaan pada setiap variabel. Data hubungan antar variabel-variabel terkait dianalisis menggunakan uji korelasi Spearman.

\section{HASIL DAN PEMBAHASAN}

Karaktersistik Contoh dan

Keluarganya

Diketahui bahwa rata-rata umur suami dan istri, yaitu 42.16 tahun dengan kisaran 27 tahun sampai 58 tahun untuk suami dan 39.22 tahun dengan kisaran 25 tahun sampai 52 tahun untuk istri. Tidak satupun dari keluarga contoh baik suami maupun istri yang tidak tamat Sekolah Menegah Atas (SMA). Sebagian besar contoh dan suaminya berpendidikan Perguruan Tinggi dengan tingkatan Strata 1, yaitu sebesar 38 persen contoh dan 52 persen pada suaminya. Sebagian besar keluarga contoh yang diwawancara bekerja sebagai pegawai negeri, yaitu 96 persen contoh dan 56 persen pada suaminya. Proporsi terbesar keluarga contoh berasal dari keluarga kecil ( $\leq 5$ orang) sebesar 86 persen, dan keluarga sedang $(6-7$ orang) sebesar 14 persen dengan rata-rata besar keluarga sebanyak hampir 5 orang per keluarga. Hampir setengah dari keluarga contoh (42\%) mempunyai balita dan lebih dari setengah keluarga contoh (54\%) mempunyai anak usia sekolah. Hanya seperlima dari keluarga contoh yang memiliki anak berusia lebih dari 20 tahun.

Data menunjukkan bahwa hampir tiga-perempat keluarga contoh memiliki pembantu rumah tangga dengan kisaran upah seorang pembantu rumah tangga antara $\mathrm{Rp}$ 100.000-375.000 per bulan dengan rata-rata upah sebesar Rp 211.250 per bulan.

Besar Pendapatan Keluarga dan Kontribusi Contoh Terhadap Pendapatan Keluarga

Rata-rata pendapatan contoh adalah $\mathrm{Rp} 1.348 .030$ per bulan dengan kisaran Rp 400.000 sampai Rp 4.000.000 per bulan, sedangkan rata-rata pendapatan suami contoh adalah Rp 1.986.000 per bulan dengan kisaran Rp 700.000 sampai Rp 8.000.000 per bulan. Pendapatan per kapita keluarga adalah pendapatan total keluarga dibagi dengan jumlah anggota keluarga. Rata-rata pendapatan per kapita keluarga contoh adalah Rp 610.267,02 per bulan dengan kisaran Rp 242.857 sampai Rp 1.714.286 per bulan. Data yang diketahui bahwa $62 \%$ keluarga contoh memiliki pendapatan per kapita pada kelompok Rp 275.859 - Rp 551.716 per bulan. Selanjutnya, diketahui bahwa kontribusi pendapatan contoh terhadap pendapatan total keluarganya berkisar antara 25.1 - 50 persen. Berdasarkan data, diketahui bahwa tidak ada satupun dari keluarga contoh yang 
berada di bawah garis kemiskinan, atau dengan kata lain seluruh keluarga contoh berada pada tingkatan status ekonomi menengah ke atas.

\section{Karakteristik Karir Contoh}

Rata-rata lama bekerja contoh adalah 15.90 tahun dengan kisaran 1 tahun sampai 30 tahun. Sebaran terbesar lama bekerja contoh berkisar antara 16 - 20 tahun (36\%). Usia contoh pada saat pertama kali bekerja berkisar antara 19 tahun sampai 28 tahun dengan rata-rata 23.32 tahun. Sebaran terbesar usia contoh pada saat pertama kali bekerja adalah 25 tahun (20\%).

Sebaran lama jam kerja contoh antara 6 sampai 10 jam per hari dengan rata-rata 7.47 jam/hari. Sebesar 44 persen contoh menggunakan kendaraan umum untuk menuju tempat kerja, 36 persen contoh menggunakan kendaraan pribadi, 18 persen contoh jalan kaki, dan hanya 2 persen contoh yang menggunakan bus kantor sebagai alat trasportasi untuk pergi ke tempat kerja.

\section{Nilai Personal Contoh terhadap Arti} Keluarga dan Pekerjaan

Sebaran terbesar dari contoh (36\%) menganggap keluarga adalah suatu tempat ataupun wadah untuk saling berinteraksi sesama anggota keluarga baik secara fisik maupun psikis. Seluruh contoh mempunyai persepsi mengenai arti anak sebagai sesuatu hal yang diharapkan dapat menjadi penerus keluarga, sehingga perlu diberikan pendidikan dan perlindungan sebagai bagian dari human investment. Hampir setengah dari contoh (46\%) memprioritaskan kesehatan jasmani dan rohani, meliputi ketenangan jiwa, ibadah, dan kebahagiaan hidup. Sebagian besar contoh (78\%) menjawab hal yang berkaitan dengan peraturan dan keprofesionalan diri terhadap prinsip dalam bekerja. Hampir keseluruhan contoh (94\%) melakukan keseimbangan dalam menjalani aktivitas pekerjaan dan keluarga. Setengah dari contoh (50\%) memprioritaskan kebutuhan yang utama dan mendesak dalam hal mengelola keuangan keluarga.

Strategi Penyeimbangan antara Aktivitas Pekeriaan dan Keluarga

Terdapat dua jenis pernyataan (Tabel 1) dalam strategi perempuan bekerja yaitu mengenai persepsi (afektif) dan tindakan (praktek) contoh dalam menyeimbangkan antara pekerjaan dan keluarga. Kedua jenis pernyataan tersebut terbagi menjadi tiga kategori yaitu pernyataan yang mengarah ke keluarga, ke pekerjaan, dan ke strategi penyeimbangan antara pekerjaan dan keluarga.

Strategi yang dipersepsikan contoh yang memprioritaskan keluarga (26\%) adalah mengutamakan keluarga (46\%) dalam setiap kesempatan yang ada seperti menelpon ke rumah pada saat sedang kerja (18\%), dan juga selalu meminta ijin suami apabila ada tugas ke luar kota (66\%). Strategi yang dipersepsikan contoh yang memprioritaskan pekerjaan (10\%) adalah mengutamakan kepentingan pekerjaan di atas kepentingan keluarga (2\%) dan tidak membawa anak ke tempat kerja (72\%). Adapun strategi yang dipersepsikan contoh yang menyeimbangkan antara pekerjaan dan keluarga (64\%) adalah masalah di kantor tidak dapat dicampuradukkan dengan masalah di rumah (60\%). 
Tabel 1. Sebaran Contoh Berdasarkan Persepsi terhadap Strategi Perempuan Bekerja

\begin{tabular}{|c|c|c|c|c|c|c|c|}
\hline \multirow{2}{*}{ No. } & \multirow{2}{*}{ Pernyataan } & \multicolumn{2}{|c|}{ TS } & \multicolumn{2}{|c|}{$\mathrm{S}$} & \multicolumn{2}{|c|}{ SS } \\
\hline & & $\mathbf{n}$ & $\%$ & $\mathbf{n}$ & $\%$ & $\mathbf{n}$ & $\%$ \\
\hline \multirow[t]{5}{*}{1.} & \multicolumn{7}{|l|}{ Prioritas ke Keluarga } \\
\hline & $\begin{array}{l}\text { a. Keluarga adalah prioritas utama } \\
\text { dibandingkan dengan karir. }\end{array}$ & 0 & 0 & 27 & 54 & 23 & 46 \\
\hline & $\begin{array}{l}\text { b. Isteri selayaknya meminta ijin suami } \\
\text { apabila ada tugas di luar kota. }\end{array}$ & 0 & 0 & 17 & 34 & 33 & 66 \\
\hline & $\begin{array}{l}\text { c. Membawa anak ke tempat kerja pada saat } \\
\text { sedang bekerja adalah wajar. }\end{array}$ & 36 & 72 & 14 & 28 & 0 & 0 \\
\hline & $\begin{array}{l}\text { d. Hal yang wajar bagi ibu yang bekerja di } \\
\text { luar rumah untuk menelpon rumah setiap } \\
\text { hari. }\end{array}$ & 9 & 18 & 32 & 64 & 9 & 18 \\
\hline \multirow[t]{2}{*}{2.} & \multicolumn{7}{|l|}{ Prioritas ke Pekerjaan } \\
\hline & $\begin{array}{l}\text { Kepentingan anak dan suami dapat } \\
\text { dikorbankan dibandingkan dengan tugas di } \\
\text { kantor. }\end{array}$ & 46 & 92 & 3 & 6 & 1 & 2 \\
\hline \multirow[t]{2}{*}{3.} & \multicolumn{7}{|l|}{ Seimbang } \\
\hline & $\begin{array}{l}\text { Masalah kantor tidak dapat } \\
\text { dicampuradukkan dengan masalah rumah. }\end{array}$ & 2 & 4 & 18 & 36 & 30 & 60 \\
\hline
\end{tabular}

Jenis pernyataan kedua yaitu mengenai tindakan (praktek) contoh terhadap strategi bekerja dapat dilihat pada Tabel 2. Tindakan contoh dengan strategi mementingkan keluarga (2\%) adalah tidak bekerja dan melanggar perintah atasan demi keluarga walaupun masih terdapat 40 persen yang kadang-kadang melakukannya. Tindakan contoh dengan strategi mementingkan pekerjaan (6\%) sebesar 28 persen menyatakan melakukan apapun demi kemajuan karir dan sering melewatkan acara keluarga karena urusan pekerjaan (10\%). Adapun tindakan contoh dengan strategi keseimbangan antara pekerjaan dan keluarga (92\%) bersepakat dengan suami untuk saling menjaga antara pekerjaan dan keluarga $(78 \%)$ dan tidak melakukan pekerjaan kantor pada hari libur (24\%).

Apabila hasil dari Tabel 1 dan Tabel 2 disatukan, maka didapatkan strategi contoh dalam bekerja secara keseluruhan baik dilihat dari persepsi (afektif) maupun tindakan (praktek) contoh. Hasil menunjukkan bahwa rata-rata skor contoh dalam melakukan strategi antara pekerjaan dan keluarga adalah 31.68 dengan kisaran antara 27 sampai 39. Hal ini dikarenakan pada umumnya contoh telah berpengalaman dalam mengatur kehidupannya untuk memenuhi antara tuntutan keluarga dan pekerjaan. Pengalaman contoh dalam menyeimbangkan antara pekerjaan dan keluarga tersebut disebabkan karena sebagian besar contoh telah bekerja selama lebih dari 15 tahun dan sebagian besar contoh pun berada pada tahap pemantapan dalam kehidupannya apabila dilihat dari kelompok umur. 
Tabel 2. Sebaran Contoh Berdasarkan Tindakan terhadap Strategi Perempuan Bekerja

\begin{tabular}{|c|c|c|c|c|c|c|c|}
\hline \multirow{2}{*}{ No. } & \multirow{2}{*}{ Pernyataan } & \multicolumn{2}{|c|}{1} & \multicolumn{2}{|c|}{2} & \multicolumn{2}{|c|}{3} \\
\hline & & $\mathbf{n}$ & $\%$ & $\mathbf{n}$ & $\%$ & $\mathbf{n}$ & $\%$ \\
\hline \multirow[t]{5}{*}{1.} & \multicolumn{7}{|l|}{ Prioritas ke Keluarga } \\
\hline & $\begin{array}{l}\text { a. Tidak masuk kerja karena anak atau } \\
\text { suami sakit }\end{array}$ & 1 & 2 & 44 & 88 & 5 & 10 \\
\hline & $\begin{array}{l}\text { a. Menunda pekerjaan di kantor untuk } \\
\text { kepentingan anak }\end{array}$ & 4 & 8 & 35 & 70 & 11 & 22 \\
\hline & $\begin{array}{l}\text { b. Tidak mematuhi perintah atasan dengan } \\
\text { alasan kepentingan keluarga }\end{array}$ & 30 & 60 & 20 & 40 & 0 & 0 \\
\hline & $\begin{array}{l}\text { c. Pulang dari kantor lebih awal karena } \\
\text { urusan keluarga }\end{array}$ & 3 & 6 & 43 & 86 & 4 & 8 \\
\hline \multirow[t]{4}{*}{2.} & \multicolumn{7}{|l|}{ Prioritas ke Pekerjaan } \\
\hline & $\begin{array}{l}\text { a. Melakukan resiko apapun untuk } \\
\text { kemajuan karir, termasuk dipromosikan } \\
\text { ke luar kota }\end{array}$ & 36 & 72 & 14 & 28 & 0 & 0 \\
\hline & b. Melewatkan acara/urusan keluarga & 14 & 28 & 31 & 62 & 5 & 10 \\
\hline & c. Lembur di kantor atas perintah atasan & 8 & 16 & 38 & 76 & 4 & 8 \\
\hline \multirow[t]{4}{*}{3.} & \multicolumn{7}{|l|}{ Seimbang } \\
\hline & $\begin{array}{l}\text { a. Tidak melakukan pekerjaan kantor pada } \\
\text { hari libur }\end{array}$ & 3 & 6 & 35 & 70 & 12 & 24 \\
\hline & $\begin{array}{l}\text { b. Bersepakat dengan suami untuk menjaga } \\
\text { keseimbangan antara karir dan keluarga }\end{array}$ & 0 & 0 & 11 & 22 & 39 & 78 \\
\hline & $\begin{array}{l}\text { c. Suami membantu saya mengurus rumah } \\
\text { dan anak apabila saya sibuk dengan } \\
\text { pekerjaan di kantor }\end{array}$ & 3 & 6 & 24 & 48 & 23 & 46 \\
\hline
\end{tabular}

Selain itu, banyaknya contoh yang melakukan keseimbangan ini sesuia dengan pernyataan Poesposoetjipto (1996) dalam Saleha (2003) bahwa seorang perempuan dalam budaya Timur terpandang dan disegani bila ia mampu membina keluarga yang sejahtera. Kriteria keberhasilan ditentukan oleh peran yang dibawakannya sebagai seorang isteri dan seorang ibu serta bila ia mampu menjaga keseimbangan antara tugas dan tanggung jawabnya dalam bisnis tempat ia bekerja dengan tugas dan tanggung jawabnya sebagai isteri dan ibu di rumah.

Pada strategi yang lebih memprioritaskan pekerjaan, terdapat dua orang contoh yang melakukannya. Apabila dilihat lebih dalam, ternyata salah satu dari contoh tersebut tidak mempunyai anak balita dan anak usia sekolah, akan tetapi mempunyai tiga orang anak remaja. Keluarga contoh pun hanya terdiri dari keluarga inti dan tanpa pembantu rumah tangga. Ketiadaan pembantu rumah tangga diduga karena anaknya sudah dapat melakukan segala sesuatunya dengan mandiri. Dilihat dari tingkat pendidikan, baik contoh maupun suami adalah lulusan Perguruan Tinggi dengan tingkatan Strata 1. Berdasarkan pengalaman bekerja, dari awal contoh sudah bekerja sebagai pegawai negeri sipil (PNS) selama 13 tahun. Jenis pekerjaan contoh tidak berbeda dengan suami. Setiap harinya contoh bekerja selama 8 jam di kantor. Pendapatan contoh tidak berbeda dengan pendapatan suami yaitu sebesar Rp 1.100.000 per bulan. Adapun rumah yang ditempati oleh keluarga contoh adalah rumah sewa, yang artinya keluarga contoh belum memiliki rumah sendiri dan setiap bulannya keluarga contoh mengalokasikan dana untuk membayar sewa rumah. 
Tabel 3. Sebaran Contoh Berdasarkan Kategori Strategi Perempuan Bekerja dalam Menyeimbangkan antara Aktivitas Pekerjaan dan Rumah Tangga

\begin{tabular}{|l|c|c|}
\hline \multicolumn{1}{|c|}{ Kategori Strategi Perempuan Bekerja } & \multicolumn{2}{c|}{ Jumlah } \\
\cline { 2 - 3 } & $\mathbf{n}$ & $\mathbf{\%}$ \\
\hline Prioritas ke keluarga (skor16 - 26.6) & 0 & 0 \\
\hline Seimbang (skor 26.7 - 37.3) & $\mathbf{4 8}$ & $\mathbf{9 6}$ \\
\hline Prioritas ke pekerjaan (skor 37.4-48) & 2 & 4 \\
\hline Total & 50 & 100 \\
\hline
\end{tabular}

Kehidupan sosial dan kesehatan mental/emosi contoh berada pada kondisi yang baik. Akan tetapi contoh menerima dukungan sosial yang tidak terlalu baik (sedang). Manajemen sumberdaya keluarga yang dijalani oleh contoh berada pada kategori sedang. Begitupun pada hasil yang diterima untuk kesejahteraan keluarga contoh berada pada kategori sedang.

Keadaan keluarga contoh yang termasuk sederhana, dilihat dari kepemilikan rumah serta pendapatan suami dan contoh, diduga penyebab contoh lebih memprioritaskan pekerjaan daripada keluarga karena contoh ingin meningkatkan taraf hidupnya. Sehingga nantinya contoh berada pada kategori baik dalam kesejahteraan keluarga terutama dari segi ekonomi.

Contoh kedua yang lebih memprioritaskan pekerjaan daripada keluarga ternyata baru berusia 25 tahun dan suaminya pun baru berusia 27 tahun, serta baru mempunyai seorang anak balita yang berusia delapan bulan. Akan tetapi, keluarga contoh tidak mempunyai pembantu rumah tangga dan tidak seorang pun dari keluarga besar contoh yang ikut tinggal bersama. Dilihat dari tingkat pendidikan, contoh merupakan lulusan Perguruan Tinggi dengan tingkatan Strata 1 akan tetapi suami contoh adalah lulusan SMA. Berdasarkan pengalaman bekerja, tidak berbeda jauh dengan contoh pertama bahwa dari awal bekerja contoh sudah bekerja sebagai pegawai negeri selama 3 tahun. Adapun jenis pekerjaan suami contoh adalah sebagai pegawai swasta. Berbeda dengan contoh pertama dalam jam kerja contoh kedua setiap harinya bekerja selama 7.5 jam sehari di kantor. Hal ini disebabkan contoh kedua mempunyai anak balita sedangkan contoh pertama tidak mempunyai anak balita. Dalam hal pendapatan, contoh mempunyai pendapatan yang berbeda dengan suaminya. Pendapatan contoh per bulan sebesar Rp 800.000 per bulan sedangkan pendapatan suami Rp 1.500.000 per bulan. Adapun rumah yang ditempati oleh keluarga contoh adalah rumah sendiri akan tetapi belum lunas, yang artinya setiap bulannya keluarga contoh mengalokasikan dana untuk membayar cicilan rumah.

Baik dalam kehidupan sosial maupun kesehatan mental/emosi contoh berada pada kondisi sedang. Begitupun dengan dukungan sosial yang diterima contoh juga berada pada kondisi sedang. Adapun manajemen sumberdaya keluarga yang dijalani oleh contoh berada pada kategori sedang dalam hal waktu dan pekerjaan serta stress. Akan tetapi contoh dapat mengatur keuangan keluarganya dengan baik. Ternyata kepuasan contoh terhadap kesejahteraan keluarganya berada pada taraf sedang.

Adanya balita dalam keluarga contoh serta tidak terdapatnya pembantu rumah tangga dan keluarga besar yang dapat membantu contoh 
merupakan hal yang tidak mungkin bagi contoh untuk lebih memprioritaskan pekerjaan. Pada saat bekerja, anak contoh tersebut dititipkan pada keluarga terdekat. Sehingga contoh dapat melakukan kegiatannya di kantor dengan lebih leluasa. Selain itu, contoh baru bekerja selama tiga tahun, sehingga contoh masih giat dalam melakukan pekerjaannya.

Alokasi Waktu Sebagai Aplikasi Strategi Penyeimbangan antara Aktivitas Pekerjaan dan Rumah Tangga Berdasarkan hasil pada Tabel 4 didapatkan informasi bahwa pada saat hari libur contoh mengalokasikan waktunya untuk kegiatan domestik dua kali lipat dari hari kerja. Hal ini menandakan bahwa contoh bertanggung jawab dalam melaksanakan tugasnya sebagai seorang ibu dan istri. Selain kegiatan domestik, contoh juga lebih banyak melakukan kegiatan personal pada hari libur daripada hari kerja. Kegiatan personal ini mencakup merawat diri seperti luluran, creambath, olah raga dan lain sebagainya dengan maksud menyenangkan suami yang merupakan salah satu tugas dari seorang istri.

Tabel 4. Sebaran Jenis Waktu Berdasarkan Hari Kerja, Hari Libur, dan Rata-rata dalam Satu Minggu

\begin{tabular}{|l|c|c|c|c|c|c|}
\hline \multirow{2}{*}{ Jenis Waktu } & \multicolumn{2}{c|}{ Hari Kerja } & \multicolumn{2}{c|}{ Hari Libur } & \multicolumn{2}{c|}{ Rata-rata } \\
\cline { 2 - 7 } & jam & \% & jam & \% & jam & \% \\
\hline Produktif & 8.09 & 33.71 & 0.68 & 2.83 & 5.97 & 24.88 \\
\hline Domestik & 3.16 & 13.17 & 6.14 & 25.58 & 4.01 & 16.71 \\
\hline Personal & $\mathbf{9 . 9 0}$ & $\mathbf{4 1 . 2 5}$ & $\mathbf{1 1 . 3 9}$ & $\mathbf{4 7 . 4 6}$ & $\mathbf{1 0 . 3 2}$ & $\mathbf{4 3 . 0 0}$ \\
\hline Sosial & 1.23 & 5.12 & 3.30 & 13.75 & 1.82 & 7.58 \\
\hline Santai & 1.63 & 6.79 & 2.49 & 10.38 & 1.88 & 7.3 \\
\hline Total & 24.00 & 100.00 & 24.00 & 100.00 & 24.00 & 100.00 \\
\hline
\end{tabular}

Pada Tabel 4 terlihat adanya waktu yang dialokasikan oleh contoh untuk kegiatan produktif (2.83\%) pada hari libur. Terdapat seperlima dari contoh (20\%) yang melakukan aktivitas produktif pada hari libur yang hampir sepertiganya bekerja selama 1 jam (30\%). Pada contoh yang melakukan aktivitas produktif pada hari libur, diantaranya contoh yang berprofesi sebagai dosen (40\%), bekerja di rumah sakit (30\%), dan bekerja di Pemerintahan Daerah Kabupaten Bogor (30\%).

Pada rata-rata waktu harian, ternyata rata-rata waktu produktif contoh lebih tinggi dibandingkan ratarata waktu domestik yang artinya dalam keseharian contoh lebih banyak melakukan kegiatan produktif daripada kegiatan domestik. Penelitian yang dilakukan oleh Berheide, Berk, dan Berk (1976) dalam Puspitawati (1992) menunjukkan bahwa semakin banyaknya waktu yang digunakan perempuan untuk bekerja, semakin sedikit waktu yang digunakan untuk melakukan pekerjaan rumah tangga.

Peran Keluarga Besar dalam Membantu Wanita Bekerja untuk Menyeimbangkan Aktivitas Pekerjaan dan Keluarga

Selain pembantu rumah tangga, keluarga besar juga dapat membantu perempuan bekerja dalam menyeimbangkan antara pekerjaan dan keluarga. Adanya dukungan baik dari keluarga maupun dari lingkungan selain keluarga terhadap perempuan bekerja untuk tetap bisa melaksanakan tugasnya sebagai 
seorang pekerja sekaligus sebagai isteri dan ibu sangatlah dibutuhkan.

Terdapat lima jenis pernyataan mengenai dukungan sosial yang dirasakan oleh contoh, yaitu pernyataan yang berkaitan keluarga inti (suami dan anak), keluarga besar, teman, lingkungan kerja, dan lingkungan tempat tinggal. Diketahui bahwa sebagian besar contoh mendapatkan dukungan sosial yang baik dari suami, keluarga besar, teman, lingkungan kerja, dan lingkungan tempat tinggal.

Berdasarkan komposit dari semua pernyataan dukungan sosial didapatkan hasil bahwa hampir duapertiga dari contoh (62\%) mendapatkan dukungan sosial yang baik. Hal ini mendukung contoh dalam melakukan keseimbangan antara pekerjaan dan keluarga. Hasil penelitian mengungkapkan bahwa hampir keseluruhan dari contoh (96\%) melakukan keseimbangan tersebut. Rata-rata skor dukungan sosial sebesar 55.04 dengan kisaran antara 44 sampai 67. Contoh yang mendapatkan dukungan sosial yang baik adalah contoh yang mendapatkan bantuan dari kerabat ataupun sanak saudaranya untuk menjaga rumah ataupun mengasuh anak apabila contoh pergi kerja. Sedangkan contoh yang menerima dukungan sosial yang berada pada kategori sedang adalah contoh yang terkadang sulit mendapatkan ijin dari atasannya demi kepentingan keluarga. Adapun contoh yang kurang baik dalam menerima dukungan sosial adalah contoh yang merasa dikecam oleh keluarganya atau suami contoh sebetulnya tidak suka contoh bekerja di luar rumah.

\section{Kesejahteraan Keluarga}

Kesejahteraan keluarga yang diteliti adalah keadaan yang dirasakan (perceived) contoh yang meliputi kesejahteraan fisik, ekonomi, sosial, dan psikologis. Kesejahteraan keluarga secara fisik terdiri dari keadaan kesehatan contoh dan keluarga; secara ekonomi terdiri dari keadaan keuangan, makanan, tempat tinggal, pakaian, dan materi/aset; secara sosial terdiri dari keadaan pendidikan, manajemen sumberdaya keluarga, pekerjaan, dan hubungan komunikasi antar sesama anggota keluarga serta komunikasi dengan keluarga besar dan lingkungan di luar keluarga; secara psikologis terdiri dari keadaan mental dan spiritual contoh dan keluarga.

Hasil menginformasikan bahwa persentase terbesar contoh merasa puas sampai sangat puas terhadap keadaan tempat tinggal keluarga $(50 \%)$, keadaan pekerjaan contoh $(50 \%)$, keadaan pekerjaan suami (56\%), hubungan/komunikasi antara suami dan contoh (74\%), hubungan/komunikasi antara orang tua dengan anak (70\%), hubungan/komunikasi antara keluarga dengan keluarga besar (52\%), hubungan/komunikasi antara keluarga dengan tetangga (54\%), kelakuan/kepribadian anak (54\%), keadaan mental keluarga (56\%), keadaan mental contoh (50\%), dan keoptimisan keluarga menatap masa depan (48\%). Sedangkan sebagian kecil contoh merasa sangat tidak puas terhadap keadaan tempat tinggal keluarga (4\%), keadaan tabungan keluarga (6\%), alat transportasi untuk kerja (2\%), dan aset pendukung karir yang ada di rumah, seperti hp, komputer, internet, dll (2\%).

Secara garis besar, proporsi terbesar keluarga contoh (76\%) berada pada kesejahteraan keluarga tingkatan sedang (skor 71 - skor 111), yang berarti contoh merasa cukup puas terhadap hubungan komunikasi antara anggota keluarganya, keadaan pakaian keluarga, dan keadaan mental keluarga.

\section{Hubungan antara Variabe}

Hasil analisis hubungan

(Lampiran 1) menunjukkan rata-rata waktu domestik dan rata-rata waktu personal memiliki hubungan yang 
nyata $(p<0.05)$ dengan strategi penyeimbangan. Rata-rata waktu domestik berhubungan negatif terhadap strategi penyeimbangan. Artinya semakin tinggi rata-rata waktu yang digunakan contoh untuk melakukan kegiatan domestik maka contoh lebih memprioritaskan keluarga daripada pekerjaan. Sedangkan ratarata waktu personal memiliki sifat hubungan yang positif, yaitu semakin tinggi rata-rata waktu yang digunakan contoh untuk kegiatan personal maka contoh lebih memprioritaskan pekerjaan daripada keluarga. Hal ini disebabkan contoh yang lebih mengutamakan pekerjaan daripada keluarga akan memiliki kecenderungan manajemen stress serta kesehatan mental yang kurang, sehingga contoh lebih banyak menghabiskan waktu untuk melakukan kegiatan personal, seperti tidur, guna untuk melepaskan segala beban yang ditanggung oleh contoh, terutama beban pekerjaan.

Tidak terdapat hubungan yang nyata ( $p>0.05$ ) antara dukungan sosial dengan strategi penyeimbangan. Akan tetapi, sifat hubungan dari kedua variabel tersebut adalah negatif. Hal tersebut menggambarkan bahwa semakin tinggi dukungan sosial yang diterima oleh contoh, maka contoh akan lebih mengutamakan keluarga daripada pekerjaan. Terlihat bahwa sebagian besar contoh masih menganut budaya timur yaitu meskipun contoh bekerja di luar rumah tetap tidak melupakan kewajiban sebagai seorang ibu dan contoh.

Berdasarkan hasil uji korelasi Spearman, dukungan sosial memiliki hubungan yang nyata $(p<0.01)$ terhadap kesejahteraan keluarga sebesar $38.7 \%$. Artinya semakin besar dukungan sosial yang diterima oleh contoh maka semakin tinggi tingkat kesejahteraan keluarga contoh. Didapatkan hasil bahwa kesejahteraan keluarga berhubungan nyata positif dengan jumlah pembantu rumah tangga dan pendapatan suami serta dukungan sosial keluarga besar, namun berhubungan negatif dengan kontribusi pendapatan contoh terhadap pendapatan total keluarga.

Hasil penelitian ini menunjukkan adanya hubungan nyata $(p<0.01)$ yang negatif antara strategi penyeimbangan dengan kesejahteraan keluarga yang berarti bahwa semakin contoh memprioritaskan pekerjaan lebih besar dari pada keluarga, maka cenderung menurunkan tingkat kesejahteraan keluarga baik fisik, sosial maupun psikologis. Sebaliknya, apabila contoh semakin memprioritaskan keluarga lebih besar daripada pekerjaan, maka cenderung meningkatkan tingkat kesejahteraan keluarga baik fisik, sosial maupun psikologis.

\section{SIMPULAN DAN SARAN}

Simpulan

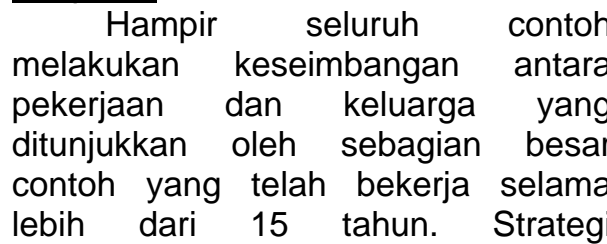
penyeimbangan antara aktivitas pekerjaan dan keluarga berhubungan nyata negatif dengan rata-rata waktu domestik dan rata-rata waktu personal. Kesejahteraan keluarga berhubungan nyata positif dengan jumlah pembantu rumah tangga dan pendapatan suami serta dukungan sosial keluarga besar, namun berhubungan negatif dengan kontribusi pendapatan contoh terhadap pendapatan total keluarga. Didapatkan hasil adanya hubungan nyata $(p<0.01)$ yang negatif antara strategi penyeimbangan dengan kesejahteraan keluarga yang berarti bahwa semakin contoh memprioritaskan pekerjaan lebih besar dari pada keluarga, maka cenderung menurunkan tingkat kesejahteraan keluarga baik fisik, sosial maupun psikologis. Sebaliknya, apabila contoh semakin memprioritaskan keluarga lebih besar daripada pekerjaan, maka cenderung 
meningkatkan tingkat kesejahteraan keluarga baik fisik, sosial maupun psikologis.

\section{Saran}

Perempuan bekerja yang memiliki balita, disarankan untuk memiliki pembantu rumah tangga. Selain itu juga perlu adanya penelitian lanjutan mengenai perbedaan strategi penyeimbangan dan hubungannya dengan kesejahteraan keluarga pada perempuan yang mempunyai suami bekerja di luar kota atau di dalam kota, juga antara perempuan dari keluarga tunggal dan keluarga utuh.

\section{DAFTAR PUSTAKA}

Badan Pemberdayaan Masyarakat Daerah [BAPEDA]. 2002. Kebijakan Pembangunan Pemberdayaan Perempuan. BAPEDA, Bandung.

Biro Pusat Statistik [BPS]. 2002a. Profil Wanita Indonesia. BPS, Jakarta. 2002b. Statistik Kestik. Statistik KesPusaka, Jakarta. . 2004a. Kabupaten Bogor dalam Angka Tahun 2003. BPS, Bogor. . 2004b. Kota Bogor dalam Angka Tahun 2003. BPS, Bogor.

Garis-garis Besar Haluan Negara [GBHN]. 2002. GBHN 1999-2004. Pustaka Setia, Bandung.

Gunarsa, S.D. \& Y.S.D. Gunarsa. 2001. Psikologi Praktis: Anak, Remaja, dan Keluarga. BPK Gunung Mulia, Jakarta.

Human Development and Family Studies, College of Family and Consumer Science, lowa State University.

Kammeyer, K.C.W. 1987. Marriage and Family : a Foundation for Personal Decisions. Allyn \& Bacon, Massachusetts.

Lasswell, M. \& T. Lasswell. 1987. Marriage and the Family. Wadsworth Publishing Company, California.

Nicholson, W. 2001. Teori Ekonomi Mikro: Prinsip Dasar dan Pengembangannya (Deliarnov, penerjemah). RajaGrafindo Persada, Jakarta.
Puspitawati, H. 1992. Time Management Strategies Used in Households in Which Income is Generated at Home. Tesis Major Family Environment, Department

Saleha, Q. 2003. Manajemen Sumberdaya Keluarga : Suatu Analisis Gender dalam Kehidupan Keluarga Nelayan di Pesisir Bontang Kuala, Kalimantan Timur. Tesis Master Departemen Gizi Masyarakat dan Sumberdaya Keluarga, Fakultas Pertanian, Institut Pertanian Bogor.

Suhendi, H. \& R. Wahyu. 2001. Pengantar Studi Sosiologi Keluarga. Pustaka Setia, Bandung.

Widodo, P. T. 2004. Pembagian kerja dan sumbangan pendapatan kaum perempuan pada keluarga miskin. Wara Demografi, 34 (4), 32-39.

Winter, M. \& H. Puspitawati. 1993. Time Management Strategies Used By Households with Home-Based Work. Journal of Family and Economic Issues, 14 (1), Spring 1993.

1 Departemen IImu Keluarga dan Konsumen, IPB

2 Departemen Gizi Masyarakat dan Sumberdaya Keluarga, IPB

Alamat Korespondensi: Herien Puspitawati

Departemen Ilmu Keluarga dan Konsumen, Fakultas Ekologi Manusia IPB

Jl. Lingkar Kampus IPB Darmaga 16680

Telp. (0251) 8628303, Fax. (0251) 8627432 